\title{
\begin{tabular}{l|ll} 
ISSN & $: 2662-5514$ \\
e-ISSN & $: 2654-6981$ \\
DOI & $: 10.9744 /$ ahec.1.1.31-36
\end{tabular}
}

\section{Strategies to Meet the Challenges Of Global Education: Prospects of Asian Higher Education}

\author{
Sabur Khan \\ Chairman \\ Daffodil International University, Bangladesh \\ Email: chairman@daffodilvarsity.edu.bd
}

Since human development is a key input to the goal of inclusive and shared economic growth and poverty alleviation, we need to put considerable emphasis on human development. Human capital, in a broad sense, includes education, skills, training, health and other related factors of work forces that determine their overall productivity and capacity to seize opportunities created by economic progress. In this globalized world, the idea and thoughts of internationalization of higher education especially in developing countries like Bangladesh has been deduced from globalization of education process.

The widely adopted human capital view is that higher education increases skill and knowledge which result in higher income. According to the Executive Summary of the Future of Jobs Employment, Skills and Workforce Strategy for the Fourth Industrial Revolution (World Economic Forum 2016) "By one popular estimate, 65\% of children entering primary school today will ultimately end up working in completely new job types that don't yet exist. In such a rapidly evolving employment landscape, the ability to anticipate and prepare for future skills requirements, job content and the aggregate effect on employment is increasingly critical for businesses, governments and individuals in order to fully seize the opportunities presented by these trends - and to mitigate undesirable outcomes". This context leads us to design better strategies for designing architecture of new courses which will best fit future job skills.

With the impact of development in information technology and globalization, obtaining jobs for young graduates have become competitive all over the world more than ever before. The innovative developments in technology work changes the socio-economic system, and nature of work which increases the scopes to university graduates. It has been observed that in this competitive and changing environment, achievement depends on people's knowledge, capacity of doing work, acquired skills, and how fast they are capable to adjust to the changes around. In this phenomenon, higher education must consider the needs of the stakeholders, community and society and the university graduates need to develop their capacities in terms of employability and experiential learning. Reportedly, industries lack of skill constraint and skill mismatch of the university graduates. In view of this, higher education institutions need to address new sets of skills to develop the graduate globally competitive.

Technology Integration and Higher Education: At this age of information technology, the digitization of all process is taking place, gradually. Viewing this, the integration of Information Technology (IT) in teaching is very critical for ensuring quality in education. IT integration in teaching learning will make it a lot easier, attractive and more effective to communicate ideas and complex subjects meaningfully in class rooms. In addition, use of IT in teaching will encourage students to use e-contents to improve learning, access e-resources for studying and research, use information technology for academic preparation and problem solving. 


\section{AUPF.}

\section{Globalization and Higher Education Components}

We need to recognize the integral role of human development in the pursuit of a prosperous nation, and should advocate measures to ensure that development is indeed inclusive so that the benefits can be equitably shared by all. In this era of globalization, the objectives, goals and missions of higher/university education have undergone profound change all over the world. Information and communication technology has brought forth a global knowledge revolution.

To educate the graduates with practical knowledge, educators should focus in redesigning of many components like Research, Pedagogy, and curriculum. In establishing a sustainable system and policy, not only localization of higher education is important, but internationalization and regional cooperation are also equally important to get the momentum and positive output. Asia now becomes the hub of all developments, especially in Higher Education. Cooperation need to be enhanced in the domains of higher education, among Asian economies.

In global practice, the quality of education and research could not match the horizontal increase. Educationists stress on changing the landscape of higher education through proper enhancement of quality of higher education and research and cooperation which can play a vital role. The most important aspects of quality education generally refers the quality of teaching learning and research.

Internationalization and globalization are perceived as a key reality in the 21 st century, influencing profoundly higher education. Higher education systems and higher education institutions need to define the equilibrium between national priorities and local needs and international setting. So, the cooperation among countries becomes inevitable to establish and ensure quality education.

In arecent report on 'Productivity in Higher Education Research insights for universities and governments in Asia' ${ }^{1}$ by Asian Productivity Organization (APO) the following rationales were addressed:

"Understanding and improving the productivity of higher education is of growing sectoral as well as broader relevance to Asia and the world. Higher education is playing an increasingly important role in Asia. Between 1980 and 2050, the center of higher education gravity is being seen as shifting eastward, and Asia now has more higher education students and a growing research impact. In summary, there are a plethora of growing rationales to care about the productivity of higher education, such as":

- "The higher education sector is growing in scale and significance in many economies".

- "Most traditional academic approaches do not scale well, thus escalating costs and spurring a need for new education and associated business models."

- "The growth in scale is creating affordability constraints for governments, and in many countries, more private forms of finance are being sought."

\footnotetext{
${ }^{1}$ Productivity in Higher Education Research insights for universities and governments in Asia. (2017). Asian Productivity Organization. Retrieved from https://www.apo-tokyo.org/publications/wpcontent/uploads/sites/5/eReport-Productivity_in_Higher_Education_Oct2017.pdf
} 


\section{\begin{tabular}{l|ll} 
ISSN & $: 2662-5514$ \\
e-ISSN & $: 2654-6981$ \\
DOI & $: 10.9744 /$ ahec.1.1.31-36
\end{tabular}}

- "Institutional leaders are examining pricing scenarios to maximize new revenues from tuition fees."

- "Regulators are striving to understand the economies of higher education to prevent institutions from price gauging."

- "Cross-subsidizations inherent in traditional university models are becoming harder to justify in more transparent contexts."

\section{Mobility of International Students}

The mobility of international students currently becomes an important policy issue all over the world. The recent exponential growth is driven by the demand for a knowledge-based economy and highly skilled human resources globally.

There are many reasons why students pursue their education abroad. For some, it is a chance to broaden cultural and intellectual horizons. Others go abroad to avoid the frustrations of under- resourced universities at home. Many have no choice but to go abroad in other to pursue a particular field of education or type of academic program. These are just some of the factors that can push students to pursue educational opportunities outside of their home countries $^{2}$.

Globally, the effects of demographic transition on economic growth have recently got a renewed attention in policy discourses which lead to the address of the issue of international students' mobility. According to the Global Monitoring Report (2015), a 1.0 percentage point increase in the working age population (15-64) has been estimated to enhance per-capita GDP by 1.1 to 2 percentage points.

Bangladesh is a populous country and has been experiencing significant changes in her demographic structure. Now, Bangladesh can reap its demographic dividend byinvesting in human capital (education) to foster opportunities for developing a skilled work force. Education directs young people to learn skills for higher-quality jobs, and these jobs promote economic development of a country. Through these investments, nations can ensure development of labor force well equipped to capitalize new opportunities that emerge from a demographic dividend.

Today, there are 42 public universities and 103 private universities in Bangladesh ${ }^{3}$. Those public universities are solely funded by the Government and private universities are funded by private stakeholders. In the circumstances, the public university enjoys many financial supports and grants for education and research including the activities for internationalization. There is no well-documented policy exist for internationalization of Higher Education in the country. However, a number of scholarships are offered by the Government of Bangladesh for higher education leading to Ph.D. programs abroad. The University Grants Commission (UGC) of Bangladesh, the statutory apex body in the field of higher education in Bangladesh provides a number of scholarships for Bangladeshi academics for research leading to $\mathrm{Ph}$. $\mathrm{D}$. degrees inside the country. Out of 103 private universities, only few universities take active part in internationalization of academic, cocurricular and extra-curricular activities. Of them, Daffodil International University (DIU) actively focuses on internationalization practice guided by its well formulated policy and

\footnotetext{
${ }^{2}$ http://www.uis.unesco.org/Library/Documents/international-student-mobility-asia-pacific-education-2013en.pdf

${ }^{3}$ http://www.ugc-universities.gov.bd/home/university/private/75
} 


\section{A. ISSN $\begin{array}{ll}: 2662-5514 \\ \text { e-ISSN } & : 2654-6981 \\ \text { DOI } & : 10.9744 / \text { ahec.1.1.31-36 }\end{array}$}

successfully able to create a good number of arrangements for exchanges of students and faculty members with reputed universities in several countries.

\section{International Student Mobility: Daffodil International University Case}

International Exchange Programs bring benefits to students by providing them with opportunities to have international exposure, to acquaint with new cultures and global educational standards. Such types of activities are vital components of overall development of students which help them to adopt alternative, multi-faceted approaches of learning. With the ever changing global economic dynamics, international exchange programs are becoming workable and effective increasing prospects of learning and gaining international experiences and exposure as well.

Currently, the international students' exchange policy of Daffodil International University (DIU) includes Outbound and Inbound Exchange Programs. In addition, faculty exchange policy is also considered. Studying abroad under Student exchange programmes is an integral part of an international education curriculum. Outbound programmes for students can last one month or less, like summer and winter schools, or one or more semesters. Presently, there are about 10 students involved in long-term exchange programmes (one semester or more). DIU has entered into several Memoranda of Understanding Agreement of academic exchange programme with universities in Turkey, Malaysia, Indonesia, India, South Korea and study abroad program agreement with Hertford College, Oxford, UK. DIU has made few subjects compulsory in Bachelor of Entrepreneurship (BE) and Masters in Public Health (MPH) which need to undertake in mobility programmes.

\section{Outbound Exchange Programs}

Under outbound exchange programs of Daffodil International University, students spend one or more semesters in a university/institute abroad. The program may also be for a short duration of one month or even less than one month. The following rules will apply to students going abroad under outbound exchange programs.

The students, who complete at least three semesters (that is one complete year) in Daffodil International University and obtain a minimum CGPA of 3.0 out of 4.0 are eligible for participating in outbound exchange programs.

- The board will select candidates based on proficiencies in language, subject matter and other social skills.

- The Director will forward the list of successful candidates to the Vice-Chancellor for the final approval.

- Prior to participating in an outbound exchange program, the student must arrange for freezing his semester activity in Daffodil International University by submitting an application to Registrar through concerned Head of the Department. The process of freezing all formalities will be free of any charges.

- The duration and number of semesters to be frozen depend on the period for which the student will stay abroad.

- The students joining the outbound exchange programs will bear travel, food, lodging and other incidental expenses. In this regard an undertaking signed between the sponsor/guardian of the student and Director, International Affairs.

\section{Transfer of Credits for Outbound Exchange Programs}

For transfer of credits, the student must apply to the Registrar. This will be applicable only for undergraduate programs and equivalent course and for course completed with CGPA of 


\section{A. ISSN $\begin{array}{ll}: 2662-5514 \\ \text { e-ISSN } & : 2654-6981 \\ \text { DOI } & : 10.9744 / \text { ahec.1.1.31-36 }\end{array}$}

minimum "B" (that is CGPA 3 out of 4). However, in any exceptional case the equivalence committee's decision will be final. For transfer of credits, students must submit original transcripts and the prescribed syllabuses of the university concerned. Daffodil International University will accept the credits of only successful candidates within the program.

\section{Rationale for an Outbound Mobility Strategic Policy of DIU}

\begin{tabular}{|l|l|}
\hline $\begin{array}{l}\text { Institutional } \\
\text { Benefits }\end{array}$ & $\begin{array}{l}\text { - Exposure of International Engagement } \\
\text { - Opportunities to involve in international projects and funding }\end{array}$ \\
\hline Brand Focus & - Job availability for highly skilled \\
& - Attractive for potential students
\end{tabular}

Table 1: Rationale for an Outbound Mobility Strategic Plan

\section{Outbound Mobility Stakeholders}

\begin{tabular}{|c|c|}
\hline Internal & External \\
\hline $\begin{array}{l}\text { - Current Students } \\
\text { - Outbound Mobility Staff } \\
\text { - Other International Office Staff } \\
\text { - Academics } \\
\text { - Senior Executives } \\
\text { - Domestic Marketing } \\
\text { - Career Department Centre } \\
\text { (CDC) } \\
\text { - Legal / Finance Sections } \\
\text { - Project Teams }\end{array}$ & $\begin{array}{l}\text { - Local industry } \\
\text { - International industry } \\
\text { - Language training partners } \\
\text { - Service providers } \\
\text { - Students' parents } \\
\text { - Media } \\
\text { - Prospective Students: High School, vocational } \\
\text { - } \text { level students, international students] } \\
\text { - Government: Ministry of Education, University } \\
\text { - Industry and Accrediting Bodies } \\
\text { UN agencies: UNESCO, UN }\end{array}$ \\
\hline
\end{tabular}

Table 2: Outbound Mobility Stakeholders

\section{Inbound exchange programs}

Foreign students willing to join inbound exchange programs in Daffodil International University for one or more semesters must apply to the Director, International Affairs through the proper authority of his/her university. The following policy will be applicable for inbound exchange programs.

- Inbound exchange program will be applicable to the Government (Ministry of Education or relevant organizations) universities/institutions of that country. 


\section{\begin{tabular}{l|ll} 
ISSN & $: 2662-5514$ \\
e-ISSN & $: 2654-6981$ \\
DOI & $: 10.9744 /$ ahec.1.1.31-36
\end{tabular}}

- Candidates for availing this program must have obtained "B" or equivalent in their native university, and original transcripts and other relevant papers should be submitted with the application. The application should also contain a consent letter from his/her parent university. The student must be proficient in English language. After successful completion of course(s) in DIU, the student will be awarded an official transcript/ certificate for those course(s).

- Registration, tuition, residential requirement and other fees will be charged as per existing rules of the university. However, tuition fee may be waived as per agreement between the two universities.

- In exceptional cases, students having CGPA slightly less than B may be considered eligible for the program, provided the authorities of both parties agree.

\section{DIU Short Term Mobility Programs in Asia}

Observing the general traits of Bangladeshi students in Higher Education, it has been found that the students are introvert towards the new environment and less exposure at international level. Basically, very few students attend a higher level educational institutions in Bangladesh from urban areas. Only few of them have knowledge and experience on travelling outside the country.

\section{DIU objectives to create the opportunity for the students}

- Support DIU students to have an overseas study experience and overseas higher education students from eligible exchange locations to have a learning experience globally.

- Enhance the skills and expertise of DIU students through access to a variety of study opportunities in Asia and the Pacific.

- Increase cooperation between DIU and higher education institutions beyond boundary.

- Facilitate student exchange to promote an increased understanding and recognition of DIU at overseas.

- Train and nourish students of DIU with diverse knowledge received from outside the country too.

- Encourage more students to become more Asia-literate.

\section{Benefits of Asia Short Mobility Programs for DIU students}

Exposure to Internationalization

The experience gained through this initiative is helping DIU to ensure internationalization through knowing each other, networking and rapport building.

\section{Students' Development}

Students are able to know the diversity in Teaching-learning, culture, sports and globalization through this initiative. This also creates an opportunity for the students to make international networking and rapport building.

\section{Intercultural experience}

Studying abroad provides a complete experience of a foreign culture through living, eating, studying, travelling, meeting local peoples and networking with new international friends. It is a sheer opportunity for students to meet and learn from their international peers. 


\section{\begin{tabular}{l|ll} 
ISSN & $: 2662-5514$ \\
e-ISSN & $: 2654-6981$ \\
DOI & $: 10.9744 /$ ahec.1.1.31-36
\end{tabular}}

International Courses and Lectures

Short Term Summer Schools Camp students study courses that may not be available at their home universities or that take a different approach to the subject matter. Students participated in these camps, learn from international lecture sessions while taking courses in their subject area blended with local knowledge.

International Peer Learning

International peer learning is one of the key benefits that international summer camps offer their students to learn from the experience of their international fellows/classmates.

\section{Learning through English}

Both English and non-English speaking countries are offering students the opportunity to take courses through English. When studying in an English-speaking country, students interact in English which helps them to improve their communication skills in an authentic environment. However, for non-native English speaking country this sort of facility is not available.

\section{Practical Learning}

International summer camps focus on more practical emphasis on the learning experiences offered to their students. Visiting academicians, industry/venture experts with opportunity to visit enterprises allow participants to observe what they learn in the academic program put into practice in real-life situations.

\section{Stand Out with Foreign Academic Credit}

Studying at an international summer camp will allow participants to take courses not readily offered at home university. It is true that employers recognize the benefits of international knowledge and exposure when looking for the next generation of high-achieving employees.

International Experience at Low Cost

International summer camp offers the students (comparatively of low-income group) who would like to study abroad the opportunity to benefit from the study-abroad experience without the higher costs of a full semester or year overseas.

\section{Hosted own Summer Program}

Daffodil International University, with its experience, hosted 3 summer camp programs (in 2018) using international standard facilities which provides quality education. In this context, International Affairs of DIU is working relentlessly to materialize as it has good exposure in international education arena. In 2018, DIU hosted 3 (three) Summer Programs which are: Winter Camp, during January 2018 (33 participants participated), International Social Business Summer program (the participants were from 16 different countries) and Youth for SDG Summer Camp during August, 2018 (15 international participants attended).

Cooperation among Asian universities enhance the quality of education at higher education arena. In this age of fourth industrial revolution (Industry 4.0), stakeholders need to increase the networking and collaboration in different domains of higher education like research and extension, pedagogical issue, accreditation and ranking. For future development, the Asian countries must consider these issues to make its people capable to tackle the future challenges 
\begin{tabular}{l|ll} 
ISSN & $: 2662-5514$ \\
e-ISSN & $: 2654-6981$ \\
DOI & $: 10.9744 /$ ahec.1.1.31-36
\end{tabular}

\section{References}

Productivity in Higher Education Research insights for universities and governments in Asia. (2017). Asian Productivity Organization

Data for Sustainable Development. UNESCO Institute for Statistics (UIS) Retrieved from http://uis.unesco.org/

Executive Summary of the Future of Jobs Employment, Skills and Workforce Strategy for the Fourth Industrial Revolution. Retrieved from http://www3.weforum.org/docs/WEF_FOJ_Executive_Summary_Jobs.pdf 